ISSN 1392-3196 / e-ISSN 2335-8947

Zemdirbyste-Agriculture, vol. 106, No. 4 (2019), p. 351-358

DOI 10.13080/z-a.2019.106.045

\title{
Yielding and fruit quality of several cultivars and breeding clones of Amelanchier alnifolia grown in north-eastern Poland
}

\author{
Anna BIENIEK ${ }^{1}$, Bogumił MARKUSZEWSKI ${ }^{1}$, Jan KOPYTOWSKI ${ }^{1}$, Stanisław PLUTA ${ }^{2}$, \\ Jarosław MARKOWSKI ${ }^{2}$ \\ ${ }^{1}$ University of Warmia and Mazury \\ Prawocheńskiego 21, 10-720 Olsztyn, Poland \\ E-mail: anna.bieniek@uwm.edu.pl \\ ${ }^{2}$ Research Institute of Horticulture \\ Konstytucji 3 Maja 1/3, 96-100 Skierniewice, Poland
}

\begin{abstract}
This study was aimed at evaluating fruit yield and fruit quality of five Polish selective clones (S, H, N, 2/1 and 3/1) and three Canadian cultivars ('Smoky', 'Martin' and 'Pembina') of Saskatoon berry (Amelanchier alnifolia Nutt.) cultivated under the conditions of north-eastern Poland. The mean yield per shrub as well as the mean 100 fruit weight and fruit number per bunch was determined in the years 2010-2017. The contents of sugars, anthocyanins and polyphenols were examined by the high-performance liquid chromatography (HPLC) method. Macroelements in fruits were determined after digestion by wet mineralization $\left(\mathrm{H}_{2} \mathrm{~S}_{4}\right)$ using oxidant hydrogen peroxide $\left(\mathrm{H}_{2} \mathrm{O}_{2}\right)$. The analysis of experimental data showed that the mean yields of the analysed cultivars and clones of Saskatoon berry in the first seven years of their fruiting reached $1.33 \mathrm{~kg}$ per shrub, which gave a yield of $5.5 \mathrm{t} \mathrm{ha}^{-1}$. The statistical analysis of results showed significant differences between the tested genotypes. The highest yields were reported for the Polish clones S and 3/1, whereas the lowest ones - for the clone N. The clone S belonged to one of the groups with the lowest values of 100 fruit weight and fruit number per bunch, whereas the clone $3 / 1$ was characterized by later fruit ripening and by a higher fruit weight and number per bunch. Considering the contents of chemical components in fruits, the clone $\mathrm{S}$ had the highest active acidity, dry matter and sorbitol contents, but the lowest content of anthocyanins. In turn, fruits of the clone $3 / 1$ were the richest in magnesium (Mg). Among the three Canadian cultivars analysed in our study, the highest yields were recorded for the 'Martin', whose fruits were the largest and had the highest content of anthocyanins. The lowest fruit yield was determined for the cultivar 'Smoky', but its fruits were the richest in total polyphenols.
\end{abstract}

Key words: chemical composition, mineral elements, Saskatoon berry, yielding.

\section{Introduction}

The Saskatoon berry (Amelanchier alnifolia Nutt.) belongs to the family Rosaceae. In Poland, this species has so far not been widely used in the commercial cultivation. In recent years, there has been an interest in this species as a supplement or alternative for growing currants and chokeberry (Aronia melanocarpa L.) by Polish growers. It has been cultivated for over 30 years in North America, particularly in Canada (Seliga, Pluta, 2016). In Europe, it is cultivated on a small scale in Finland, Lithuania and Latvia (Jagła, 2013). The first breeding and selection work on the Saskatoon berry was carried out in Canada. The result of that work was creation of many valuable cultivars, including 'Smoky', 'Martin', 'Northline', 'Honeywood', 'Thiessen' and others (Zatylny et al., 2005). Over the last two decades new Saskatoon berry cultivars have been bred in the
Czech Republic (Rop et al., 2012). A new breeding program with Saskatoon berry was also started in Poland in 2009, aimed at developing new cultivars better adapted to the Polish climatic conditions and producing high quality fruit (Żurawicz et al., 2014).

The Saskatoon berry is a shrub or a small tree with various growth forms from small and branchy to compact and slender, and from 1 to $8 \mathrm{~m}$ in height depending on the cultivar. It is very resistant to frosts reaching even up to $-50^{\circ} \mathrm{C}$, which is its great advantage enabling its cultivation in the countries of colder climate. Due to climatic conditions, the range of species that can be introduced to commercial cultivation in the countries of north-eastern Europe is limited (Bieniek et al., 2016).

Shrubs of Saskatoon berry start fruiting 3-4 years after planting and reach the full yielding in the

Please use the following format when citing the article:

Bieniek A., Markuszewski B., Kopytowski J., Pluta S., Markowski J. 2019. Yielding and fruit quality of several cultivars and breeding clones of Amelanchier alnifolia grown in north-eastern Poland. Zemdirbyste-Agriculture, 106 (4): $351-358$. DOI $10.13080 / \mathrm{z}-\mathrm{a} .2019 .106 .045$ 
$6^{\text {th }}-7^{\text {th }}$ year of cultivation. They may be grown on a plantation for even 30-50 years. In addition, they may be cultivated using bio-methods, which respond to recent consumer preferences that search for healthy food products in non-contaminated environment. Fruit of this species look like small pome (apples). They are red to purple to nearly black at maturity, grow up to $10-15 \mathrm{~mm}$ in diameter, maturing at the end June - beginning of July. The fruits are sweet, tasting somewhat like a blueberry, strongly accented by the almond-like flavour of the seeds (Lachowicz et al., 2017 b). Saskatoon berry fruits may be consumed fresh, but are also a valuable raw material in the food processing industry for the manufacture of juices, wines, fruit liqueurs, jams, jellies and fruit pies. The fruits of Saskatoon berry are a rich source of phenolics, flavonoides, minerals, vitamins, lipids and anthocyanins, known for their valuable healing properties (BakowskaBarczak, Kołodziejczyk, 2008; Mazza, Cottrell, 2008; Rop et al., 2012; Żurawicz et al. 2014; Jin et al., 2015; Lachowicz et al., 2017 a; b). Special interest is raised by the antidiabetic and anticarcinogenic potential of fruits and leaves (Zatylny et al., 2005). Ample investigations have suggested cyanidin and its glycosides found in fruits of Saskatoon berry to be bioavailable compounds, which serve antioxidative, antimutagenic, anticarcinogenic and anti-inflammatory functions and to evoke an alleviating effect on the gastrointestinal tract (Juríkova et al., 2013). Fruits of this species are characterized by high contents of bioactive components.
In addition, their sugar to acids ratio is typical of berry fruits, which provides a unique possibility of their use as natural ingredients neutralizing the sour taste of other processed fruit products. This trait may become useful in the design of new categories of functional foods. It also contributes to a growing interest in Saskatoon berry fruits and their preserves expressed by both consumers and potential manufacturers (Konopacka et al., 2017).

This study was aimed at evaluating fruit yield and fruit quality of five Polish selective clones and three Canadian cultivars of Saskatoon berry cultivated under conditions of the north-eastern Poland.

\section{Materials and methods}

The experimental material included plants of Saskatoon berry (Amelanchier alnifolia Nutt.) of five Polish clones: S, H, N, 2/1 and 3/1, selected at the Research Institute of Horticulture in Skierniewice, central Poland among seedlings obtained from seeds brought from Canada, and three Canadian cultivars: 'Smoky', 'Martin' and 'Pembina'. The 'Smoky' was grown in the Alberta Province located at the 50 $55^{\circ}$ northern latitude, which corresponds to that of the north-eastern Poland $\left(53^{\circ} 50^{\prime} \mathrm{N}, 20^{\circ} 31^{\prime} \mathrm{E}\right)$. The shrubs cultivated in our experiment were not irrigated. Some climatic conditions (average temperatures and precipitation) at the experimental location in the study years and in the multi-year period of 1981-2010 are presented in Figure.

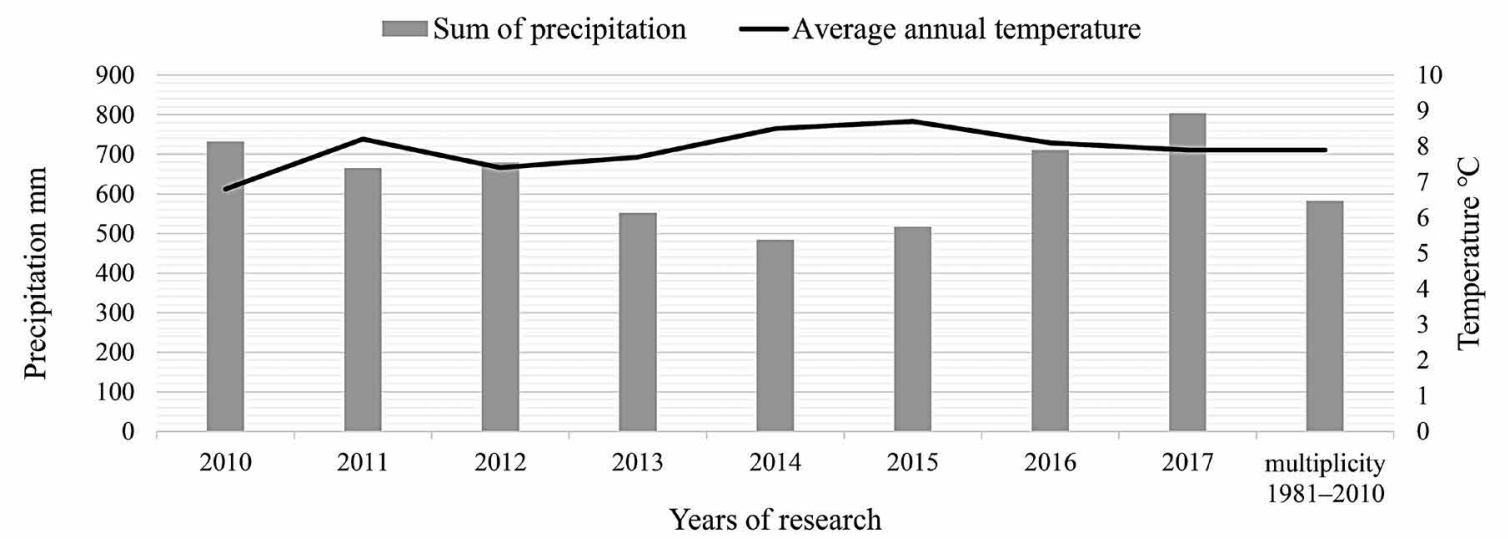

Figure. Sums of precipitation and average annual temperatures in the years 2010-2017 (data of Meteorological Station in Tomaszkowo near Olsztyn, Poland)

The plants of all genotypes (5 Polish clones and 3 Canadian cultivars) were grown in 2006-2017 in a cultivar-comparative experiment on the field of the Teaching and Experimental Station of the University of Warmia and Mazury in Olsztyn, Poland. The experiment was established in the autumn of 2006 on the soil classified as Mollic Gleysol according to WRB (2014). The soil $\mathrm{pH}$ ranged from slightly acid to neutral $(\mathrm{pH}=6.2-6.8)$, and the soil was characterized by a medium content of nutrients. Two-year seedlings of the aforementioned cultivars and selective clones were planted in two rows, in $3.0 \times 0.80 \mathrm{~m}$ spacing, in three replications of each of 6 plants. Before the beginning of fruit ripening until harvest, the plants were protected with a net against birds. Fruits were picked manually at the stage of maturity for consumption (Rogiers, Knowles, 1998).

The mean yield per shrub as well as the mean 100 fruit weight and fruit number per bunch was determined in the years 2010-2017. In 2016, rejuvenation cutting of shrubs was performed and the shrubs were not covered with a net protecting them against birds, hence this year was not considered in the compilation of study results (Table 2). In the years 2010-2014, a $0.5-\mathrm{kg}$ sample of randomly selected fruits was prepared for chemical analyses from each analysed genotype. Immediately after harvest, the fruits were frozen in plastic containers at a temperature of $-25^{\circ} \mathrm{C}$. The samples intended for analyses were disintegrated in a frozen state. Analytical weighted portions were collected from composite laboratory sample of disintegrated fruits.

Dry matter (DM) content was determined by drying samples at $105^{\circ} \mathrm{C}$ at reduced pressure (PN$90 / \mathrm{A} / 75101 / 03$. Fruit and vegetable products), total soluble solids - by refractometry according to the standard PN-EN 12143:2000 (Fruit and vegetable products. Determination of the content of soluble substances by 
refractometric method). Soluble solids were determined using ATAGO PR-101 refractometer (ATAGO, Japan). Results were expressed in \%. Titratable acidity was determined by standard titration method using an automatic titration unit DL 50 Graphix (Mettler Toledo, Switzerland) by titration with $0.1 \mathrm{~N} \mathrm{NaOH}$. Total acidity was expressed as citric acid content in \% according to the standard PN-90/A/75101/04 (Fruit and vegetable products. Determination of the content of total acidity).

Active acidity $(\mathrm{pH})$ was determined by potentiometric method PN-90/A-75101/06. The determination consisted of the measurement of the potential difference between specific electrodes immersed in the tested solution. The electrode with a constant and known potential was the reference electrode for the second electrode, whose potential was a function determined by the acidity. The acidity measurement was carried out three times (read with an accuracy of 0.05).

For analyses of monosaccharides, saccharose and sorbitol contents, the frozen and disintegrated fruits $(5 \mathrm{~g})$ were homogenized in $20 \mathrm{~mL}$ of distilled water; afterwards the solution was transferred quantitatively to $50 \mathrm{~mL}$ flask. The mixture was centrifuged at $10.000 \times \mathrm{g}$ for 10 minutes. Contents of sugars were determined using the high-performance liquid chromatography (HPLC) method EN 12630:1999 (Fruit and vegetable juices. Determination of glucose, fructose, sorbitol and sucrose contents) with Agilent HP 1100 system equipped with a refractive index detector. Before injection into column HPX $87 \mathrm{C}, 300 \times 5 \mathrm{~mm}$, particle size $5 \mu \mathrm{m}$ (Bio-Rad, Switzerland), samples were purified on a column Poly Prep, $0.8 \times 4 \mathrm{~cm}$ (Bio Rad, USA) with AG 1-X8 anion exchange resin (Markowski et al., 2015). The content of anthocyanins was determined by the spectrophotometric method (Wrolstad, 1993)

The content of total polyphenols was determined by the spectrophotometric method modified by Tsao and Yang (2003). Fruit extract $(0.4 \mathrm{~mL})$ diluted in $70 \%(\mathrm{v} / \mathrm{v})$ of methanol was mixed with $1.6 \mathrm{~mL}$ of $7.5 \%$ sodium carbonate solution. Then, $2 \mathrm{~mL}$ of FolinCiocalteau reagent was added and the mixture was shaken. Absorbance was measured at a wavelength of $765 \mathrm{~nm}$ against a blank sample after 30 minutes of sample storage at a room temperature in the dark. The results were expressed in gallic acid equivalents per 100 $\mathrm{g}$ of fruits.

Table 1. Origin of plants, term of their fruit harvest, yield, 100 fruit weight and bunch characteristics of Saskatoon berry genotypes (mean results for the years 2010-2017)

\begin{tabular}{|c|c|c|c|c|c|c|}
\hline Genotype & $\begin{array}{l}\text { Country } \\
\text { of origin }\end{array}$ & $\begin{array}{c}\text { Fruit } \\
\text { harvest }\end{array}$ & $\begin{array}{l}\text { Fruit yield } \\
\text { kg shurb-1 }^{-1}\end{array}$ & $\begin{array}{l}100 \text { fruit weight } \\
\text { g }\end{array}$ & $\begin{array}{l}\text { Fruit number } \\
\text { per bunch }\end{array}$ & $\begin{array}{c}\text { Bunch length } \\
\mathrm{cm}\end{array}$ \\
\hline Smoky & Canada & 03.07 & $1.24 \mathrm{e}$ & $93 \mathrm{de}$ & $12.16 \mathrm{~b}$ & $5.96 \mathrm{a}$ \\
\hline Martin & Canada & 03.07 & $1.43 \mathrm{c}$ & $101 \mathrm{a}$ & $13.28 \mathrm{a}$ & $6.62 \mathrm{a}$ \\
\hline Pembina & Canada & 04.07 & $1.35 \mathrm{~d}$ & $91 \mathrm{ef}$ & $11.66 \mathrm{c}$ & $6.10 \mathrm{a}$ \\
\hline $\mathrm{S}$ & Poland & 02.07 & $1.69 \mathrm{a}$ & $90 \mathrm{f}$ & $9.36 \mathrm{e}$ & $5.64 \mathrm{a}$ \\
\hline $\mathrm{H}$ & Poland & 02.07 & $1.40 \mathrm{c}$ & $84 \mathrm{~g}$ & $9.46 \mathrm{e}$ & $5.16 \mathrm{a}$ \\
\hline $\mathrm{N}$ & Poland & 02.07 & $0.88 \mathrm{~g}$ & $94 \mathrm{~cd}$ & $10.80 \mathrm{~d}$ & $5.14 \mathrm{a}$ \\
\hline $2 / 1$ & Poland & 04.07 & $1.04 \mathrm{f}$ & $98 \mathrm{~b}$ & $9.00 \mathrm{f}$ & $6.55 \mathrm{a}$ \\
\hline $3 / 1$ & Poland & 04.07 & $1.64 \mathrm{~b}$ & $96 \mathrm{bc}$ & $12.50 \mathrm{~b}$ & $6.95 \mathrm{a}$ \\
\hline Mean & & 03.07 & 1.33 & 93 & 11.03 & 6.05 \\
\hline
\end{tabular}

Note. Mean values denoted with the same letter in columns do not differ significantly at $\alpha=0.05$. analyses were carried out in three replications. Tests were prepared directly after fruit harvest using $0.5 \mathrm{~kg}$ $105^{\circ} \mathrm{C}$. The dried material was ground in a laboratory mill. Macroelements in fruits of Saskatoon berry were determined after digestion ( $1 \mathrm{~g}$ ground plant material) by wet mineralization $\left(\mathrm{H}_{2} \mathrm{~S}_{4}\right)$ using oxidant hydrogen peroxide $\left(\mathrm{H}_{2} \mathrm{O}_{2}\right)$. The mineralized material was transferred to $200 \mathrm{~cm}^{3}$ flasks. The following values were determined in the prepared samples: nitrogen $(\mathrm{N})$ - by the distillation method, phosphorus (P) - colorimetrically, by the vanadium-molybdenum method, potassium $(\mathrm{K})$, calcium $(\mathrm{Ca})$ and natrium $(\mathrm{Na})$ - by atomic emission spectroscopy (AES), magnesium $(\mathrm{Mg})$ - by atomic absorption spectroscopy (AAS). The analyses were carried out on the basis of Polish certified reference material Virginia Tobacco Leaves (CTAVTL-2). The content of macroelements was determined according to Polish Norms PN-91/R-04014 (Analysis of chemical and agricultural products. Methods of digestion of plant material for the determination of macro- and micronutrients). The following determination errors were included: $\mathrm{N}-3 \%, \mathrm{P}-4.5 \%, \mathrm{~K}-2 \%, \mathrm{Ca}-2.8 \%, \mathrm{Na}-7 \%$ and $\mathrm{Mg}-1.5 \%$.

Considering the fact that Saskatoon berry is little known species in Poland, programs for its protection and weed control have not been developed so far (Pluta et al., 2014). Therefore, no chemical plant protection against diseases and pests was used and weeds were removed mechanically and manually in the growing period.

Results were analysed statistically based on arithmetic means of three parallel samples. Differences between mean values were compared with the HSD (honestly significant difference) Tukey test and considered significant at a level of $\alpha=0.01$ for results of chemical analyses and at $\alpha=0.05$ for all other results. Calculations were done with the software Statistica, version 12.0 (StatSoft Inc., USA).

\section{Results and discussion}

Results concerning maturation and harvest terms of fruits of the analysed genotypes (cultivars and clones) of Saskatoon berry are presented in Table 1. of randomly-selected fruits of each cultivar dried at 
Differences in terms of fruit ripening between the tested genotypes were insignificant. The earliest maturing were the fruits of clones $\mathrm{S}, \mathrm{H}$ and $\mathrm{N}-$ on the $2^{\text {nd }}$ of July on average, whereas the latest maturing ones were these of cultivar 'Pembina' and clones $2 / 1$ and $3 / 1-$ on the $4^{\text {th }}$ of July on average. In the experiment conducted in central Poland in the years 2015-2016 by Seliga and Pluta (2016) fruits of Canadian cultivars ('Martin', 'Thiessen' and 'Smoky') ripened the earliest - at the turn of June and July, and cultivar 'Pembina' and Polish clones (5/6 of types $\mathrm{N}$ and $\mathrm{S}$ ) ripened in the first half of July. The term of fruit ripening is also determined by climatic conditions occurring in a year of plant cultivation. Data presented by Seliga and Pluta (2016) were based on observations done in two years (2015-2016), whereas our experiment was conducted for seven years (2010-2017) and the mean term of fruit harvest was established on the $3^{\text {rd }}$ of July (Tables 1 and 2).
Results related to harvest term, fruit yield and fruit weight in particular study years determined for the analysed cultivars and clones of Saskatoon berry are presented in Table 2. Fruit ripening terms differed and depended to a greater extent on the study year (weather conditions) than on the genotype. The earliest term of fruit ripening was noted in $2012\left(25^{\text {th }}\right.$ of June $)$, whereas the latest one - in 2015 ( $7^{\text {th }}$ of July).

One of the key functional traits of a cultivar which determines its utility for cultivation is its productivity. The analysis of experimental data showed that the mean yields of the analysed cultivars and clones of Saskatoon berry in the first seven years of their fruiting reached $1.33 \mathrm{~kg}$ per shrub, which gave the yield of $5.5 \mathrm{tha}^{-1}$ (Table 2). The statistical analysis of results showed significant differences between the tested genotypes. The highest yields were reported for the Polish clones S and 3/1 (1.69 and $1.64 \mathrm{~kg} \mathrm{shrub}^{-1}$,

Table 2. Fruit harvest term, yield and 100 fruit weight of Saskatoon berry in the years 2010-2017 (mean results for all genotypes)

\begin{tabular}{|c|c|c|c|c|}
\hline \multirow{2}{*}{$\begin{array}{l}\text { Experimental } \\
\text { years }\end{array}$} & \multirow{2}{*}{$\begin{array}{c}\text { Fruit } \\
\text { harvest }\end{array}$} & \multicolumn{2}{|c|}{ Fruit yield } & \multirow{2}{*}{$\begin{array}{c}100 \text { fruit weight } \\
\mathrm{g}\end{array}$} \\
\hline & & kg per shrub & $\mathrm{tha}^{-1}$ & \\
\hline 2010 & 30.06 & $0.13 \mathrm{~g}$ & $0.50 \mathrm{~g}$ & $86 \mathrm{e}$ \\
\hline 2011 & 01.07 & $0.36 \mathrm{f}$ & $1.50 \mathrm{f}$ & $68 \mathrm{f}$ \\
\hline 2012 & 25.06 & $1.20 \mathrm{e}$ & $5.00 \mathrm{e}$ & $68 \mathrm{f}$ \\
\hline 2013 & 28.06 & $1.75 \mathrm{e}$ & $7.30 \mathrm{c}$ & $99 \mathrm{c}$ \\
\hline 2014 & 01.07 & $1.95 \mathrm{~b}$ & $8.01 \mathrm{~b}$ & $108 \mathrm{~b}$ \\
\hline 2015 & 07.07 & $2.37 \mathrm{a}$ & $9.90 \mathrm{a}$ & $89 \mathrm{c}$ \\
\hline 2017 & 06.07 & $1.57 \mathrm{~d}$ & $6.50 \mathrm{~d}$ & $132 \mathrm{a}$ \\
\hline Mean & 03.07 & 1.33 & 5.50 & 93 \\
\hline
\end{tabular}

Note. Mean values denoted with the same letter in columns do not differ significantly at $\alpha=0.05$.

respectively), whereas the lowest ones - for the clone $\mathrm{N}$ $\left(0.88 \mathrm{~kg} \mathrm{shrub}^{-1}\right)$. In the experiment conducted in central Poland, after two years of yielding of a few cultivars of Saskatoon berry, the highest mean fruit yields were determined for shrubs of the clones $\mathrm{S}$ and $\mathrm{N}$, i.e. 2.8 and $2.5 \mathrm{~kg}$, respectively, whereas the smallest mean yield, i.e. $0.4 \mathrm{~kg}$, was recorded for shrubs of 'Pembina' (Seliga, Pluta, 2016). According to St-Pierre et al. (2005), this cultivar reached poor yields also in Canada. This is inconsistent with the results of our study and with the findings reported earlier by McConkey (1979) and St-Pierre (1997), who demonstrated high yields of 'Pembina' in the climatic and soil conditions of Canada. Analysis of our experimental results showed that under conditions of the north-eastern Poland the highest mean yields were obtained for all studied genotypes of Saskatoon berry in the years 2014 and 2015 , namely in the $8^{\text {th }}$ and $9^{\text {th }}$ year of their cultivation, and reached $1.95 \mathrm{~kg} \mathrm{shrub}^{-1}\left(8.1 \mathrm{tha}^{-1}\right)$ and $2.37 \mathrm{~kg} \mathrm{shrub}^{-1}$ (9.9 $\mathrm{t} \mathrm{ha}^{-1}$ ), respectively. In 2016, strong rejuvenating pruning was performed, during which a few oldest shoots were removed from each shrub. Therefore, this year was not considered in the data compilation. In the next year (2017), however, the mean yield reached $1.57 \mathrm{~kg} \mathrm{shrub}^{-1}\left(6.5 \mathrm{tha}^{-1}\right)$ for all genotypes. According to Jagła (2013), Saskatoon berry plants start to bear fruits in $3^{\text {rd }}-5^{\text {th }}$ year after planting, when their yields range from 2.5 to $5.0 \mathrm{t} \mathrm{ha}^{-1}$. The maximal fruit yields are recorded in the $7^{\text {th }}-8^{\text {th }}$ year of cultivation and may range from 8 to $10 \mathrm{tha}^{-1}$, depending on the cultivar and even $15 \mathrm{t} \mathrm{ha}^{-1}$ on irrigated plantations. The choice of cultivars is the key of significance for potential producers of fruits of this crop. As shown in our experiment, 'Martin' was best fruiting among Canadian cultivars, whereas among the Polish selections it was the clone $\mathrm{S}$ - its fruit yield was even higher compared to the Canadian cultivars (Table 1).

From consumers' perspective, one of the more important indicators of fruit quality is size (Czernyszewicz, 2011). In our experiment, it was defined as the weight of 100 randomly selected fruits, which enabled determining the usability of fruits of the tested cultivars and clones of Saskatoon berry for various purposes (fresh market or processing industry). The mean 100 fruit weight differed significantly among the analysed Saskatoon berry genotypes (Table 1) and study years (Table 2). Considering genotype, its values ranged from $84 \mathrm{~g}$ for the clone $\mathrm{H}$ to $101 \mathrm{~g}$ for cultivar 'Martin'. In the years 2011 and 2012, the tested genotypes produced the smallest fruits and the mean 100 fruit weight accounted for $68 \mathrm{~g}$. It was probably caused by the weather conditions and aging of the bushes grown in the experiment. In turn, in 2017 they produced the largest fruits (132 g 100 fruits $^{-1}$ on average), as influenced mainly by rejuvenating pruning of the shrubs (Table 2). Their fruit size could also be affected by the weather conditions in particular experimental years, including both temperatures and precipitation. The highest fruit yields were obtained in the years 2014 and 2015, which were the warmest and characterized by the lowest sum of precipitation (Fig.). In 2017, the value of the mean annual temperature was the same as the multi-year average (1981-2010), while the annual sum of precipitation was 
the highest among all analysed years and exceeded the annual sum of precipitation from the multi-year period by $221.4 \mathrm{~mm}$. In this year, the mean weight of fruits of the studied cultivars and clones was significantly higher compared to the previous experimental years.

The mean value of 100 fruit weight determined in all study years for the genotypes evaluated in our study under the conditions of north-eastern Poland reached 93 g. In turn, in the experiment conducted under the conditions of the north-western Poland, Ochmian et al. (2013) reported that the mean weight of 100 fruits of Saskatoon berry was $98 \mathrm{~g}$. In the study carried out by Zatylny et al. (2005) in Canada, the mean fruit weight determined for 16 cultivars of Saskatoon berry analysed in the years 1998-2000 ranged from 0.79 to $1.66 \mathrm{~g}$. The weight of fruits of 'Martin' was the highest (1.66 g), whereas the smallest fruits were produced by 'Smoky' and 'Pembina' (1.09 and $0.85 \mathrm{~g}$, respectively). The mean weight of fruits determined for all cultivars reached 114 $\mathrm{g}$ and was slightly higher compared to the value obtained in our experiment.
Apart from fruit weight, the fruit number in a bunch is a typical trait of crops which produce fruits in bunches, including the Saskatoon berry. In the years 2010-2017, the mean fruit number per bunch determined in the analysed genotypes of Saskatoon berry amounted to 11 , whereas mean bunch length - to $6 \mathrm{~cm}$ (Table 1). The highest number of fruits in a bunch was found for cultivar 'Martin' (13.28), and the lowest one (9.00) - for the clone $2 / 1$. The shortest bunches $(5.14$ and $5.16 \mathrm{~cm})$ were noted in the clones $\mathrm{N}$ and $\mathrm{H}$, while the longest ones $(6.95 \mathrm{~cm})$ in the clone $3 / 1$. Similar results were reported by Seliga and Pluta (2016) in their studies conducted in central Poland.

The results of fruit chemical analyses of the tested genotypes are given in Tables 3-5. Mean contents of dry matter and total soluble solids, mean values of active acidity and mean contents of total organic acids in fruits of the analysed cultivars and clones of Saskatoon berry were significantly different (Table 3 ).

Mean dry matter content analysed in fruits of the studied cultivars and clones reached $21.68 \%$. Its highest

Table 3. Content of dry matter, total soluble solids, values of active and titratable acidity in fruits of Saskatoon berry genotypes (mean results from the years 2010-2014)

\begin{tabular}{ccccc}
\hline Genotype & $\begin{array}{c}\text { Dry matter } \\
\%\end{array}$ & $\begin{array}{c}\text { Total soluble solids } \\
\%\end{array}$ & $\begin{array}{c}\text { Active acidity } \\
(\mathrm{pH})\end{array}$ & $\begin{array}{c}\text { Titratable acidity } \\
\%\end{array}$ \\
\hline Smoky & $21.5 \mathrm{ab}$ & $14.68 \mathrm{ab}$ & $3.99 \mathrm{ab}$ & $0.57 \mathrm{ab}$ \\
Martin & $21.35 \mathrm{ab}$ & $14.75 \mathrm{ab}$ & $3.89 \mathrm{a}$ & $0.60 \mathrm{~b}$ \\
Pembina & $21.36 \mathrm{ab}$ & $15.50 \mathrm{ab}$ & $3.99 \mathrm{ab}$ & $0.58 \mathrm{ab}$ \\
$\mathrm{S}$ & $24.14 \mathrm{~b}$ & $17.30 \mathrm{~b}$ & $4.17 \mathrm{~b}$ & $0.39 \mathrm{c}$ \\
$\mathrm{H}$ & $22.86 \mathrm{ab}$ & $16.13 \mathrm{ab}$ & $4.15 \mathrm{~b}$ & $0.40 \mathrm{c}$ \\
$\mathrm{N}$ & $20.85 \mathrm{a}$ & $14.49 \mathrm{ab}$ & $4.03 \mathrm{~b}$ & $0.52 \mathrm{a}$ \\
$2 / 1$ & $21.23 \mathrm{ab}$ & $14.35 \mathrm{ab}$ & $3.91 \mathrm{a}$ & $0.57 \mathrm{ab}$ \\
$3 / 1$ & $20.18 \mathrm{a}$ & $14.07 \mathrm{a}$ & $3.99 \mathrm{ab}$ & $0.57 \mathrm{ab}$ \\
\hline Minimum & 21.13 & 14.72 & 3.98 & 0.50 \\
\hline Maximum & 22.24 & 15.60 & 4.05 & 0.55 \\
\hline Average \pm SD & $21.68 \pm \mathbf{2 . 3 7}$ & $15.16 \pm \mathbf{1 . 8 8}$ & $4.01 \pm \mathbf{0 . 1 6}$ & $0.52 \pm \mathbf{0 . 0 9}$ \\
\hline
\end{tabular}

Note. Mean values denoted with the same letter in columns do not differ significantly at $\alpha=0.01$; SD - standard deviation of the mean.

value was determined in fruits of the clone $\mathrm{S}(24.14 \%)$, and it was significantly different from the values obtained for the clones $3 / 1$ and $\mathrm{N}(20.18 \%$ and $20.85 \%$, respectively) (Table 3). Lachowicz et al. (2017 b), who analysed fruits of the same genotypes of Saskatoon berry cultivated in central Poland in 2016, reported a slightly higher mean

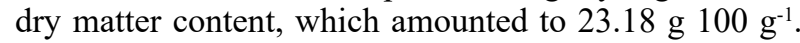
In the studies of the above-cited authors, dry matter contents determined in fruits of 'Smoky' and 'Martin' were similar to these reported in our study. These results were also comparable to those obtained in fruits of these cultivars grown in the Czech Republic (Rop et al., 2012) and Canada (Zatylny et al., 2005). In contrast, Zatylny et al. (2005) and Lachowicz et al. (2017 b) showed higher dry matter and total soluble solids in fruits of cultivar 'Pembina' compared to our findings.

The mean of total soluble solids of the analysed fruits was $15.16 \%$ (Table 3 ). Fruits of the clone $3 / 1$ were characterized by the lowest content $(14.07 \%)$ of total soluble solids; the highest content $(17.30 \%)$ was recorded in the fruits of clone $\mathrm{S}$.

In our experiment, the mean $\mathrm{pH}$ value measured for the tested genotypes reached 4.01, and the mean of titratable acidity reached $0.52 \%$. Fruits of the clones $\mathrm{S}$ and $\mathrm{H}$ were characterized by a significantly higher active acidity and the lowest content of titratable acidity compared to the analysed cultivars and other genotypes. Significantly the lowest $\mathrm{pH}$ value and titratable acidity were determined in fruits of the clones $2 / 1$ and $\mathrm{N}$ (Table 3). According to Lachowicz et al. (2017 b), the average value of $\mathrm{pH}$ of the fruits of analysed cultivars of Saskatoon berry was 3.7; the lowest value (3.02) was obtained for 'Pembina' and the highest for 'Smoky' (3.95). In our experiment, the same $\mathrm{pH}$ value (3.99) was determined in fruits of 'Smoky' and 'Pembina'. Compared to the study conducted by Lachowicz et al. (2017 b), the $\mathrm{pH}$ value determined in fruits of 'Smoky' was the same, but in fruits of 'Pembina' it was slightly lower.

Results of fruit analysis in regard to the content of glucose, fructose, sorbitol, anthocyanins and polyphenols are presented in Table 4. Significant differences were found only in the sorbitol content. The highest content of this sugar was found in fruits of the

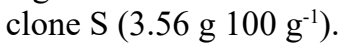

According to Lachowicz et al. (2017 b), fructose, sorbitol, glucose and sucrose were the main sugars analysed in the Saskatoon berry genotypes. Fructose and glucose are known to be sweeter than sucrose; therefore, these sugars determined the sweetness of fruits of the Saskatoon berry. In the study 
Table 4. Content (g $100 \mathrm{~g}^{-1}$ of dry matter) of sugars, anthocyanins and polyphenols in fruits of Saskatoon berry genotypes (mean results from the years 2010-2014)

\begin{tabular}{cccccc}
\hline Genotype & Glucose & Fructose & Sorbitol & Anthocyanins & Polyphenols \\
\hline Smoky & $4.38 \mathrm{a}$ & $5.01 \mathrm{a}$ & $1.84 \mathrm{ab}$ & $240.47 \mathrm{a}$ & $717.94 \mathrm{a}$ \\
Martin & $4.39 \mathrm{a}$ & $5.15 \mathrm{a}$ & $1.88 \mathrm{ab}$ & $260.95 \mathrm{a}$ & $659.75 \mathrm{a}$ \\
Pembina & $4.70 \mathrm{a}$ & $5.36 \mathrm{a}$ & $1.91 \mathrm{ab}$ & $231.36 \mathrm{a}$ & $632.17 \mathrm{a}$ \\
$\mathrm{S}$ & $4.19 \mathrm{a}$ & $5.00 \mathrm{a}$ & $3.56 \mathrm{c}$ & $165.54 \mathrm{a}$ & $703.33 \mathrm{a}$ \\
$\mathrm{H}$ & $4.21 \mathrm{a}$ & $4.92 \mathrm{a}$ & $2.86 \mathrm{bc}$ & $191.31 \mathrm{a}$ & $677.06 \mathrm{a}$ \\
$\mathrm{N}$ & $4.27 \mathrm{a}$ & $4.86 \mathrm{a}$ & $2.17 \mathrm{ab}$ & $185.57 \mathrm{a}$ & $632.28 \mathrm{a}$ \\
$2 / 1$ & $4.03 \mathrm{a}$ & $4.76 \mathrm{a}$ & $1.70 \mathrm{ab}$ & $244.87 \mathrm{a}$ & $651.92 \mathrm{a}$ \\
$3 / 1$ & $4.33 \mathrm{a}$ & $4.92 \mathrm{a}$ & $1.65 \mathrm{a}$ & $244.87 \mathrm{a}$ & $630.78 \mathrm{a}$ \\
\hline Minimum & 4.15 & 4.88 & 1.99 & 202.95 & 648.05 \\
\hline Maximum & 4.47 & 5.12 & 2.41 & 232.02 & 678.26 \\
\hline Average \pm SD & $4.31 \pm 0.68$ & $5.00 \pm 0.52$ & $2.20 \pm 0.90$ & $217.49 \pm 61.85$ & $663.15 \pm 64.28$ \\
\hline
\end{tabular}

Explanation under Table 3

conducted by Lachowicz et al. (2017 a), fruits of the clone $\mathrm{S}$ had the highest contents of these sugars: 7.29

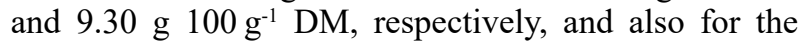

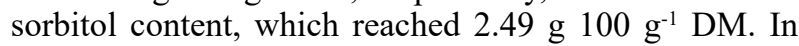
our experiment, fruits of this clone were characterized by lower contents of glucose and fructose (Table 4). The highest contents of glucose and fructose were found in fruits of 'Pembina' (4.7 and $5.36{\mathrm{~g} 100 \mathrm{~g}^{-1}}^{-1}$ DM, respectively). Lachowicz et al. (2017 b) showed slightly higher contents of these sugars in fruits of this cultivar; however, they were not the highest among the cultivars analysed by these authors. In their study, the lowest glucose content was found in the fruits of 'Martin'

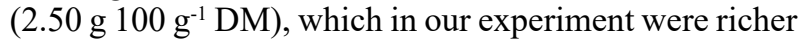

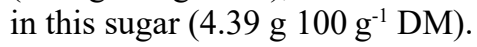

The mean content of anthocyanins in fruits of the analysed genotypes of the Saskatoon berry reached $217.49 \mathrm{mg} 100 \mathrm{~g} \mathrm{~g}^{-1}$ (Table 4) with their highest content determined in fruits of cultivar 'Martin' $(260.95 \mathrm{mg}$ $\left.100 \mathrm{~g}^{-1}\right)$ and the lowest one in the clone $\mathrm{S}(165.54 \mathrm{mg}$ $\left.100 \mathrm{~g}^{-1} \mathrm{DM}\right)$. According to Lachowicz et al. (2017 b), the highest levels of anthocyanins were found in fruits of cultivar 'Smoky' and clones S and N. The lowest content of this compound was in fruits of 'Pembina'.

The average content of polyphenols in the Saskatoon berry genotypes analysed in our study was $663.15 \mathrm{mg} 100 \mathrm{~g}^{-1} \mathrm{DM}$. The highest concentration of polyphenols was found in fruits of cultivar 'Smoky' and in clone S (average 717.94 and $703.33 \mathrm{mg} 100 \mathrm{~g}^{-1}$ $\mathrm{DM}$, respectively) and the lowest in clone 3/1 (average $\left.630.78 \mathrm{mg} 100 \mathrm{~g}^{-1} \mathrm{DM}\right)$. Lachowicz et al. (2017 a) also showed the highest contents of polyphenols in fruits of the clone S and cultivar 'Smoky': 947 and $900 \mathrm{mg}$ $100 \mathrm{~g}^{-1} \mathrm{DM}$, respectively, in 2016 . These values were higher than those obtained in our studies, but as reported by Lachowicz et al. (2017 a), the mean content of polyphenols in all cultivars analysed by them in 2016

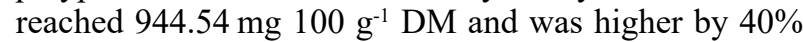
than the value reported in 2015. According to Lavola et al. (2012), the content of phenolic compounds in fruits of cultivars 'Smoky' and 'Honeywood' grown in Finland was $50 \%$ and $38 \%$ lower than in the studies by Lachowicz et al. (2017 b). However, in the study of Rop et al. (2012) the content of phenolic compounds in the fruit of 'Smoky' and 'Martin' in the Czech Republic was 46\% and 18\% lower than in the same cultivars grown in Poland.

Not all results presented in research papers may be compared with each other, because they were achieved using different analytical methods. In addition, contents of chemical compounds in fruits are significantly affected by the genotype, climatic and soil conditions, cultivation practices at the plantation, degree of fruit ripeness and study year (Bieniek et al., 2009; Lavola et al., 2012; Juríková et al., 2013; Lachowicz et al., 2017 b).

Food quality can be characterized by the content of mineral elements. They are essential for normal growth and maintenance of bones and teeth, provide electric signal transfers and are a co-factor in oxygen transport (Kang et al., 2007). The statistical analysis of the mineral composition of fruits of the analysed cultivars and selective clones of the Saskatoon berry showed significant differences only in the magnesium $(\mathrm{Mg}$ ) content. Contents of the other analysed macroelements did not differ statistically (Table 5). The highest content of $\mathrm{Mg}$ was found in fruits of the clone $3 / 1$; fruits of the remaining clones and cultivar 'Smoky' formed a homogenous group characterized by the lowest content of this element. The $\mathrm{Mg}$ is an essential element of many enzymes responsible for energy transfer. Almost all human tissues contain a small amount of $\mathrm{Mg}(\mathrm{FAO} /$ WHO, 2004).

The data presented in Table 5 showed the following order of the mean contents of individual macroelements in fruits of the analysed Saskatoon berry genotypes: $\mathrm{K}(11.72)>\mathrm{N}(11.25)>\mathrm{P}(2.25)>\mathrm{Ca}(2.09)>$ $\mathrm{Mg}(1.18)>\mathrm{Na}(0.68)$. Concerning all determined mineral elements, the $\mathrm{K}$ content was measured at the highest level in the Saskatoon berry fruit, which agrees with Mazza (2005) and Rop et al. (2012) studies. The high contents of minerals - in particular $\mathrm{K}, \mathrm{Ca}, \mathrm{P}$ and $\mathrm{Mg}$ - in fruits of the Saskatoon berry allow considering them as fruits with health-promoting properties, similarly to fruits of hardy kiwi, which has recently been introduced into cultivation also in north-eastern Europe (Bieniek et al., 2016). Bieniek (2012) and Bieniek and Dragańska (2013) reported the following order of the mean contents of the discussed macroelements in its fruits: $\mathrm{K}(16.78)>\mathrm{N}(9.8)>\mathrm{Ca}$ (3.55) $>\mathrm{P}(3.2)>\mathrm{Mg}(0.7)>\mathrm{Na}(0.65)$. In addition, these authors demonstrated that the concentration of $\mathrm{Ca}, \mathrm{N}, \mathrm{P}$, $\mathrm{Mg}$ and $\mathrm{Na}$ in fruits of Ukrainian cultivars of actinidia significantly depended (positively or negatively) on the relation between cultivars and meteorological factors in specific phenophases. The order of minerals in fruits is usually stable, but their contents depend not only on the genotype but also on the growing conditions (Gut et al., 2008; Park et al., 2014; Lachowicz et al., 2017 b). 
Table 5. The mean content ( $\mathrm{g} \mathrm{kg}^{-1}$ dry matter) of macroelements in fruits of Saskatoon berry genotypes analysed in 2010-2014

\begin{tabular}{ccccccc}
\hline Genotype & Nitrogen $(\mathrm{N})$ & Phosphorus $(\mathrm{P})$ & Potassium $(\mathrm{K})$ & Calcium $(\mathrm{Ca})$ & Magnesium $(\mathrm{Mg})$ & Natrium $(\mathrm{Na})$ \\
\hline Smoky & $10.91 \mathrm{a}$ & $2.23 \mathrm{a}$ & $9.94 \mathrm{a}$ & $1.91 \mathrm{a}$ & $1.09 \mathrm{a}$ & $0.72 \mathrm{a}$ \\
Martin & $11.23 \mathrm{a}$ & $2.52 \mathrm{a}$ & $10.40 \mathrm{a}$ & $2.38 \mathrm{a}$ & $1.26 \mathrm{ab}$ & $0.73 \mathrm{a}$ \\
Pembina & $11.19 \mathrm{a}$ & $2.17 \mathrm{a}$ & $12.03 \mathrm{a}$ & $2.14 \mathrm{a}$ & $1.22 \mathrm{ab}$ & $0.57 \mathrm{a}$ \\
$\mathrm{S}$ & $10.49 \mathrm{a}$ & $2.29 \mathrm{a}$ & $10.10 \mathrm{a}$ & $2.28 \mathrm{a}$ & $1.21 \mathrm{ab}$ & $0.64 \mathrm{a}$ \\
$\mathrm{H}$ & $11.17 \mathrm{a}$ & $2.16 \mathrm{a}$ & $10.64 \mathrm{a}$ & $1.95 \mathrm{a}$ & $1.12 \mathrm{a}$ & $0.68 \mathrm{a}$ \\
$\mathrm{N}$ & $11.29 \mathrm{a}$ & $2.31 \mathrm{a}$ & $12.43 \mathrm{a}$ & $1.90 \mathrm{a}$ & $1.11 \mathrm{a}$ & $0.77 \mathrm{a}$ \\
$2 / 1$ & $10.57 \mathrm{a}$ & $1.94 \mathrm{a}$ & $11.02 \mathrm{a}$ & $2.04 \mathrm{a}$ & $1.09 \mathrm{a}$ & $0.63 \mathrm{a}$ \\
$3 / 1$ & $13.13 \mathrm{a}$ & $2.34 \mathrm{a}$ & $13.24 \mathrm{a}$ & $2.13 \mathrm{a}$ & $1.37 \mathrm{~b}$ & $0.72 \mathrm{a}$ \\
\hline Minimum & 10.67 & 2.08 & 10.34 & 1.83 & 1.15 & 0.65 \\
\hline Maximum & 11.82 & 2.42 & 12.10 & 2.35 & 1.22 & 0.71 \\
\hline Average \pm SD & $11.25 \pm 2.45$ & $2.25 \pm 0.73$ & $11.22 \pm 3.75$ & $2.09 \pm 1.11$ & $1.18 \pm 0.15$ & $0.68 \pm 0.13$ \\
\hline
\end{tabular}

Explanation under Table 3

\section{Conclusions}

1. Among the analysed Saskatoon berry (Amelanchier alnifolia Nutt.) genotypes, the clones S and 3/1 showed the highest fruit productivity. However, the clone $\mathrm{S}$ belonged to one of the groups with the lowest values of 100 fruit weight and fruit number per bunch. The clone 3/1 was characterized by later fruit ripening and by a higher weight of fruits and higher number per bunch, in a comparison to clones $\mathrm{S}, \mathrm{H}$ and $\mathrm{N}$.

2. Fruits of the clone $\mathrm{S}$ had the lowest acidity and the highest contents of dry matter and sorbitol, but the lowest content of anthocyanins. In turn, fruits of the clone $3 / 1$ were the richest in the magnesium $(\mathrm{Mg})$ content.

3. Among the three analysed Canadian cultivars, the highest fruit yields of Saskatoon berry were recorded for 'Martin', whose fruits were the largest and had the highest content of anthocyanins. The lowest fruit yield was determined for cultivar 'Smoky', but its fruits were the richest in total polyphenols.

Received 21062018 Accepted 26062019

\section{References}

1. Bakowska-Barczak A. M., Kołodziejczyk P. 2008 Evaluation of Saskatoon berry (Amelanchier alnifolia Nutt.) cultivars for their polyphenol content, antioxidant properties, and storage stability. Journal of Agricultural and Food Chemistry, 56: 9933-9940. https://doi.org/10.1021/jf801887w

2. Bieniek A. 2012. Mineral composition of fruits of Actinidia arguta and Actinidia purpurea and some of their hybrid cultivars grown in northeastern Poland. Polish Journal of Environmental Studies, 21 (6): 1543-1550.

3. Bieniek A., Dragańska E. 2013. Content of macroelements in fruits of Ukrainian cultivars of hardy kiwifruit and Actinidia charta depending on the weather conditions during the phenological phases. Journal of Elementology, 18 (1): 23-38.

4. Bieniek A., Kopytowski J., Piłat B. 2009. Nutritional value of fruits of Ukrainian and Lithuanian black currant varieties compared to the Titania variety. Zeszyty Problemowe Postępów Nauk Rolniczych, 536: 33-43 (in Polish).

5. Bieniek A., Dragańska E., Pranckietis V. 2016. Assessment of climatic conditions for Actinidia arguta cultivation in north-eastern Poland. Zemdirbyste-Agriculture, 103 (3): 311-318. https://doi.org/10.13080/z-a.2016.103.040

6. Czernyszewicz E. 2011. Fruit quality in consumer assessment. Żywność. Nauka. Technologia. Jakość 5 (78): 173-187 (in Polish)
7. FAO/WHO. 2004. Vitamin and mineral requirements in human nutrition: report of joint FAO/WHO expert consultation, $341 \mathrm{p}$.

8. Gut M., Gasik A., Mitek M. 2008. Sea buckthorn - a plant like a pharmacy. Food Industry, 6: 36-38.

9. Jagła J. 2013. Świdośliwa - gatunek cieszący sięcoraz większym zainteresowaniem. IX konferencja sadownicza "Trendy w prawie gatunków jagodowychi pestkowych". Informator:BiuletynZwiązku Sadowników Rzeczpospolitej Polskiej, p. 24-26 (in Polish). http://188.128.135.167/ zsrpgrojec/images/stories/informator/Informator-spec.pdf

10. Jin A. L., Ozga J. A., Kennedy J. A., Koerner-Smith J. L., Botar G., Reinecke D. M. 2015. Developmental profile of anthocyanin, flavonol and pronathocyanidinin type, content and localization in Saskatoon fruits (Amelanchier alnifolia Nutt.). Journal of Agricultural and Food Chemistry, 63 (5): 1601-1614. https://doi.org/10.1021/jf504722x

11. Juríková T., Balla S., Sochor J., Pohanka M., Mlcek J., Baron M. 2013. Flavonoid profile of Saskatoon berries (Amelanchier alnifolia Nutt.) and their health promoting effects. Molecules, 18 (10): 12571-12586. https://doi.org/10.3390/molecules181012571

12. Kang I., Yu Suk Kim M. D., Choongbai Kim M. D. 2007. Mineral deficiency in patients who have undergone gastrectomy. Nutrition, 23: 318-322. https://doi.org/10.1016/j.nut.2006.05.016

13. Konopacka D., Piecko J., Mieszczakowska-Frąc M., Markowski J., Rutkowski K., Kruczyńska D., Buczek M. 2017. The Saskatoon berry - a little-known species of fruitpreliminary assessment of the suitability for processing. Przemysł Fermentacyjny i Owocowo-Warzywny, 11-12: 4-11 (in Polish). https://doi.org/10.15199/64.2017.11-12.1

14. Lachowicz S., Oszmiański J., Pluta S. 2017 (a). The composition of bioactive compounds and antioxidant activity of Saskatoon berry (Amelanchier alnifolia Nutt.) genotypes grown in central Poland. Food Chemistry, 235: 234-243.

https://doi.org/10.1016/j.foodchem.2017.05.050

15. Lachowicz S., Oszmiański J., Seliga Ł. Pluta S. 2017 (b). Phytochemical composition and antioxidant capacity of seven Saskatoon berry (Amelanchier alnifolia Nutt.) genotypes grown in Poland. Molecules, 22 (5): 853. https://doi.org/10.3390/molecules22050853

16. Lavola A., Karjalainen R., Julkunen-Titto R. 2012. Bioactive polyphenols in leaves, stems and berries of Saskatoon (Amelanchier alnifolia Nutt.) cultivars. Journal of Agricultural and Food Chemistry, 60: 1020-1027. https://doi.org/10.1021/jf204056s

17. Markowski J., Baron A., Le Quéré J-M., Płocharski W. 2015. Composition of clear and cloudy juices French and Polish apples in relation to processing technology. Food Science Technology, 62: 813-820. https://doi.org/10.1016/j.lwt.2014.11.048 
18. Mazza G. 2005. Compositional and functional properties of Saskatoon berry and blueberry. International Journal of Fruit Science, 5: 101-120.

https://doi.org/10.1300/J492v05n03_10

19. Mazza G., Cottrell T. 2008. Carotenoides and cyanogenic glucoides in Saskatoon berries (Amelanchier alnifolia Nutt.). Journal of Food Composition and Analysis, 21 (3): 249-254. https://doi.org/10.1016/j.jfca.2007.11.003

20. McConkey M. 1979. What's a Saskatoon? The pioneering and popularizing of native fruit. North American Pomona, $12(1): 2-10$.

21. Ochmian I., Kubus M., Dobrowolska A. 2013. Description of plants and assessment of chemical properties of three species from the Amelanchier genus. Dendrobiology, 70: 59-64. https://doi.org/10.12657/denbio.070.006

22. Park Y. S., Namiesnik J., Vearasilp K., Leontowicz H., Leontowicz M., Barasch D., Nemirovski A., Trakhtenberg S., Gorinstein S. 2014. Bioactive compounds and the antioxidant capacity in new kiwi fruit cultivars. Food Chemistry, 165: 354-361. https://doi.org/10.1016/j.foodchem.2014.05.114

23. Pluta S., Żurawicz E., Kucharska D. 2014. The Saskatoon berry (Amelanchier alnifolia). A new species of fruit bushes in Poland. Warsaw, Poland, 106 p. (in Polish).

24. Rogiers S. Y., Knowles N. R. 1998. Physical and chemical changes during growth, maturation, and ripening of Saskatoon (Amelanchier alnifolia) fruit. Canadian Journal of Botany, 75: 1215-1225. https://doi.org/10.1139/b97-835

25. Rop O., Řeznííčekček V., Mlček J., Juríkova T., Sochor J., Kizek R., Humpolíček P., Balík J. 2012. Nutritional values of new Czech cultivars of Saskatoon berries (Amelanchier alnifolia Nutt.). HortScience (Prague), 39: 123-128. https://doi.org/10.17221/194/2011-HORTSCI
26. Seliga Ł., Pluta S. 2016. Assessment of growth and yielding of some Saskatoon berry (Amelanchier alnifolia Nutt.) genotypes in central Poland. Zeszyty Naukowe Instytutu Ogrodnictwa, 24: 109-119 (in Polish).

27. St-Pierre R. G. 1997. Saskatoon. The brooks and Olmo register of fruit and nut varieties ( $3^{\text {rd }}$ ed.). Alexandria, USA, p. 666-668.

28. St-Pierre R. G., Zatylny A. M., Tulloch H. R. 2005. Evaluation of growth and fruit production characteristics of 15 Saskatoon (Amelanchier alnifolia Nutt.) cultivars at maturity. Canadian Journal of Plant Science, 85: 929-932. https://doi.org/10.4141/P04-066

29. Tsao R., Yang R. 2003. Optimization of a new mobile phase to know the complex and real polyphenolic composition: towards a total phenolic index using high-performance liquid chromatography. Journal of Chromatography A, 1018 (2003): 29-40. https://doi.org/10.1016/j.chroma.2003.08.034

30. WRB. 2014. World reference base for soil resources. World Soil Resources Reports No. 106. FAO, Rome.

31. Wrolstad R. E. 1993. Colour and pigment analyses in fruit products. Agricultural Experiment Station Oregon State University, Station Bulletin No. 624, 17 p.

32. Zatylny A. M., Ziehl W. D., St-Pierre R. G. 2005. Physicochemical properties of fruit of 16 Saskatoon (Amelanchier alnifolia Nutt.) cultivar. Canadian Journal of Plant Science, 85: 933-938. https://doi.org/10.4141/P04-065

33. Żurawicz E., Pluta S., Kucharska D. 2014. Amelanchier - a new berry crop in Poland with good potential for commercial cultivation. Acta Horticulturae, 1017: 251-255. https://doi.org/10.17660/ActaHortic.2014.1017.32

ISSN 1392-3196 / e-ISSN 2335-8947

Zemdirbyste-Agriculture, vol. 106, No. 4 (2019), p. 351-358

DOI 10.13080/z-a.2019.106.045

\title{
Amelanchier alnifolia veislių ir klonų derlingumas bei vaisų kokybė Lenkijos šiaurès rytuose
}

\author{
A. Bieniek ${ }^{1}$, B. Markuszewski ${ }^{1}$, J. Kopytowski ${ }^{1}$, S. Pluta ${ }^{2}$, J. Markowski ${ }^{2}$ \\ ${ }^{1}$ Varmijos Mozūrų universitetas, Lenkija \\ ${ }^{2}$ Skernievicès sodininkystės ir daržininkystès tyrimų institutas, Lenkija
}

\section{Santrauka}

Tyrimo tikslas - ivertinti alksnialapès medlievos (Amelanchier alnifolia Nutt.) atrinktų penkių lenkiškų klonų (S, H, N, 2/1 bei 3/1) ir trijų kanadietiškų veislių ('Smoky', 'Martin' bei 'Pembina'), vaisių derlių ir kokybę šiaurès rytų Lenkijos sąlygomis. 2010-2017 m. buvo nustatytas vidutinis derlius iš krūmo, vidutinè 100 vaisių masė ir vaisių skaičius kekeje. Cukrų, antocianinų ir polifenolių kiekis nustatytas efektyvios skysčių chromatografijos (HPLC) metodu. Makroelementai vaisiuose nustatyti po suardymo taikant drègną mineralizaciją $\left(\mathrm{H}_{2} \mathrm{~S}_{4}\right)$, naudojant oksidantą vandenilio peroksidą $\left(\mathrm{H}_{2} \mathrm{O}_{2}\right)$. Tyrimo duomenų analizè parodè, kad per pirmuosius septynerius derèjimo metus alksnialapės medlievos tirtų veislių ir klonų vidutinis derlius pasiekè 1,33 kg iš krūmo; tai sudare 5,5 $\mathrm{t} \mathrm{ha}^{-1}$. Tyrimo rezultatų statistinė analizè parodè reikšmingus skirtumus tarp tirtų genotipų. Didžiausi derliai gauti lenkiškų klonų S ir 3/1, mažiausias - klono N. Klonas S priklausė grupei klonų, kurių 100 uogų masè ir uogų skaičius kekejje buvo mažiausias; klonas 3/1 išsiskyre vėlyvesne vaisių branda ir didesniu vaisių mase bei skaičiumi kekẻje. Pagal cheminių komponentų kiekị vaisiuose klonas S pasižymėjo didžiausiu aktyviu rūgštumu, didžiausiais kiekiais sausujjų medžiagų ir sorbitolio, bet mažiausiu kiekiu antocianinų. Klono 3/1 vaisiai išsiskyrè didžiausiu kiekiu magnio. Iš tirtų trijų kanadietiškų veislių didžiausią derlių davè veislès 'Martin' medlievos, kurių vaisiai buvo didžiausi ir turèjo didžiausią kieki antocianinų. Mažiausią derlių davė veislès 'Smoky' medlievos, tačiau jų vaisiai turèjo didžiausią kiekị polifenolių.

Reikšminiai žodžiai: alksnialapė medlieva, cheminė sudètis, mineraliniai elementai, produktyvumas. 